\title{
Supplier integration in the assortment management of builders' merchants
}

\author{
Daniel Ellström
}

\section{Linköping University Post Print}

\section{Tweet}

N.B.: When citing this work, cite the original article.

Original Publication:

Daniel Ellström, Supplier integration in the assortment management of builders' merchants, 2015, International Journal of Retail \& Distribution Management, (43), 7, 634-651.

http://dx.doi.org/10.1108/IJRDM-03-2014-0029

Copyright: Emerald

http://www.emeraldinsight.com/

Postprint available at: Linköping University Electronic Press

http://urn.kb.se/resolve?urn=urn:nbn:se:liu:diva-121506 


\title{
SUPPLIER INTEGRATION IN THE ASSORTMENT MANAGEMENT OF BUILDERS' MERCHANTS
}

\author{
Daniel Ellström \\ Department of Management and Engineering; Linköping University; Linköping; Sweden.
}

\section{Structured abstract}

Purpose: The aim of this paper is to explore supplier integration in the assortment management of builders' merchants by identifying potential factors enabling supplier integration and potential factors mediating the success of supplier integration.

Design/methodology/approach: A qualitative case study method was used, in which interviews and participative observations were conducted with a timber supplier and builders' merchants in the UK.

Findings: The likelihood that a supplier and a retailer will implement supplier integration is positively affected by the retailer's format as a large chain with several product categories represented in its stores and the retailer's trust in the supplier. Effectiveness and efficiency of supplier integration is mediated by the number of different retail formats represented by the retailers, the ability of the supplier to determine cost drivers in its operations and a homogeneous market, meaning that local circumstances have limited effect on demand.

Research limitations/implications: The findings are exploratory and further testing of the propositions, using a wider empirical sample, is required. The paper extends theories relating to resource complementarity and suggests that a resource complementarity framework can be applied in relationships other than alliances.

Practical implications: This paper suggests when incorporation of supplier resources is possible to implement and when it is likely to succeed.

Originality/value: This paper uses a contingency perspective to explore supplier integration and targets individual buyer-supplier relationships. It uses a dyadic perspective and considers how supplier integration affects the dyad, rather than only the buyer.

Keywords: Supplier integration; resource dependence; resource-based view; supplier-retailer relationships; builders' merchants; assortment

Article Classification: Research paper 


\section{Introduction}

The increased attention given to relationship marketing during the last decades (e.g. Anderson et al., 1994; Morgan and Hunt, 1994; Weber, 2001) has created a general acceptance of the importance of integration in supply chains. Supply chain integration is considered to be a means of leveraging the core competences of the firms in a supply chain (Kim, 2013).

Most of the literature on supplier integration promotes it and encourages firms to engage in supplier integration (Frohlich and Westbrook, 2001; Narasimhan and Kim, 2002; Vachon and Klassen, 2008; Zhao et al., 2008; Lawson et al., 2009; Villena et al., 2009; Cao and Zhang, 2011). However, previous studies on supplier integration have provided inconclusive results, and it cannot be stated that more supplier integration is always better (Fabbe-Costes and Jahre, 2008). There are no fit-for-all solutions for how to share responsibilities or integrate suppliers in a buyer's operations. There have therefore been limited managerial advice for how and what to integrate (Fabbe-Costes and Jahre, 2008). From his literature review, Kim (2013) concludes that previous studies lack an in-depths analysis of the role supplier integration has for performance improvements. According to Kim (2013), a contingency perspective is needed where contextual factors are taken into consideration when interpreting the potential of supplier integration. Van der Vaart and van Donk (2008) also call for studies of individual buyersupplier relationships in order to better understand supply chain integration. An ongoing challenge in marketing research is therefore to provide an in-depth exploration of supplier integration and suggest when and why supplier integration is likely to take place.

The conditions for supplier integration are different in different kinds of settings. To understand supplier integration, this paper looks at timber suppliers integrating in the assortment management of builders' merchants (BMs). Builders' merchants are retailers from whom builders, joiners and other craftsmen buy the products they need for their businesses. As opposed to a do-it-yourself (DIY) retailer, from whom private consumers buy, individual BM branches usually have a strong influence over what products their customers purchase. This is partly due to the professional builders' more specific demands on the product assortment. As the BM branches are perceived to have the best knowledge about the builders operating in their area, they are often responsible for deciding which products to keep on their shelves.

From the point of view of the suppliers of timber to BMs, the branches' responsibility for assortment causes problems in their operations. Timber is sold at a low margin, and it is a live material that becomes old if kept in stock for too long. The differing demands between the individual BM branches create a situation in which suppliers are forced into small production runs, and thus lose their economies of scale. Sawmills must adjust their production to match the variations of the incoming logs in order to get sufficient return from the raw material. They are caught between restrictions caused by the raw material and demands from the individual BM branches. These restrictions and demands do not always match, and can cause difficulties for timber suppliers to keep prices down while responding to customer demand.

Timber suppliers are now experiencing consolidation among their customers, and megaretailers focusing on price and cost efficiency are becoming dominant in the marketplace (Guan, 2010; Brege et al., 2012). It has been argued that this new competitive landscape has created a 
need to renew the strategies and business models of the involved actors (Brege et al., 2012). One opportunity for supplier-BM dyads is to integrate the supplier in the management of the BM's assortment. If a supplier can encourage its customers to buy fast-selling products that can be part of larger production runs, this would increase the cost efficiency for the supplier.

The purpose of this paper is therefore to explore important aspects in the implementation of supplier integration in the assortment management of BMs. Specifically, this study aims to identify:

- Potential factors that enable supplier integration to be implemented

- Potential factors mediating the success of supplier integration, in terms of increased effectiveness and efficiency in the dyad between supplier and BM

The next section presents literature related to retailer assortment, supplier-retailer relationships, resource-based theory and resource dependence. After that, the research approach is presented and explanations are given to why a case study approach is selected, how participative observation is used and why interviews of a timber supplier and its BM customers are used in this case study. Then, the empirical setting in which the research was conducted is described. In the findings, the results are interpreted. The conclusions are drawn from the study and two propositions are made. The paper ends with a discussion of the managerial implications of the results and how future research about supplier integration might be carried out.

\section{Literature Review}

This paper views supplier integration from the individual firms' perspectives and from the supplier-BM dyad's perspective. The dyadic perspective focus on the conditions for creating value in the dyad when supplier integration is applied, and how this situation differs from when the supplier is not integrated. This is related to this paper's aim to explore mediators of supplier integration success. To answer this, resource-based theory is mainly used. The individual firms' perspectives focus on how the value created is shared between supplier and BM. This relates to the enablers of supplier integration targeted in this paper, and is answered mainly by using a resource dependence perspective. The concept of power is the basic building block for understanding exchanges in business relationships (Cox, 2007). As power is an integral part of resource dependence, this theoretical view is useful for understanding the involved actors' reasoning when they consider supplier integration. Other theoretical lenses, such as transaction cost theory, can be applied to analyze the phenomena of supplier integration. While these other perspectives are taken into consideration when deemed necessary, the resource-based view and resource dependence theory are chosen as main theories used to analyze supplier integration. They are chosen because the resource-based view deals with value creation and the resource dependence theory deals with value sharing.

\section{Supplier-retailer relationships}

The exchanges between retailers and their suppliers often take place between actors that are already acquainted with each other and have more or less settled the terms of trade (Varley, 2006). This simplifies the exchange and limits the resources that have to be spent during the exchange process. The closer the tie between retailer and supplier, the more efficiently the 
supplier can respond to the needs of the retailer. Because of this, closer relations between companies are becoming increasingly common (Mohr and Spekman, 1994; Mentzer et al., 2000; Gadde, 2004). This does not mean that all supplier-retailer relations are suited to handle as partnerships. In order for a partnership to occur, both commitment to the relation and trust is required from the involved actors (Morgan and Hunt, 1994). In turn, this requires the two actors to have good communication and to see benefits from the relation, among other things (Morgan and Hunt, 1994). Because this is not the case in all relations, many retailers have transactional relations with their suppliers (Mentzer et al., 2000).

Most of the current literature on supplier-retailer relations deals with category management and category captain initiatives (e.g. Aastrup et al., 2007; Bandyopadhyay et al., 2009; Lindblom et al., 2009). In category management a supplier is often given increased influence over category decisions, and this kind of collaboration between suppliers and retailers enables cost savings as well as an improved retailer offering (Bandyopadhyay et al., 2009; Lindblom et al., 2009). Category management is however also associated with a risk of opportunistic behaviour by the supplier, which can harm the retailer in several ways (Desrochers et al., 2003).

Activity interdependency in distribution channels is crossing corporate boundaries to an increasing extent, which highlights the need for coordination between firms (Gadde, 2004). This is supported by Varley (2006), who claims that the most successful retailers collaborate with their suppliers to achieve better assortment management. Aastrup et al. (2007) also suggested that closer relationships between suppliers and retailers can lead to increased value creation through, for example, the application of complementary information resources.

How the profit generated in a supplier-retailer dyad is shared between the two actors depends on their relative power. In economic literature, current share of profitability is connected to exercised power (Ailawadi et al., 1995). According to this reasoning, exercising power means that changes are made in the buyer-supplier relationship that increases the influencer's share of profit. Inspired by economic theory, management scholars have made a connection between power and profitability for actors in a distribution channel (Galbraith and Stiles, 1983; Ailawadi et al., 1995; Cook and Henderson, 1998; Collins, 2002). Increasing market power would, according to this reasoning, enable an actor to increase relative profitability.

Suppliers in today's distribution channels seldom have an advantageous power situation (Fearne et al., 2005). Supplier profits are dependent on the effort of the retailer, and these efforts cannot be directly observed by the supplier (Fadairo, 2013). The low power of suppliers is often assumed to mean high power and profitability among retailers (e.g. Burt and Sparks, 2003; Hingley, 2005b; Hingley, 2005a). However, the assumption of powerful retailers and dependent suppliers has been questioned in studies regarding the profitability of actors in distribution channels. Farris and Ailawadi (1992) noted that manufacturer profits are increasing while retailer profits remain stable, which indicates that manufacturer power increases. Messinger and Narasimhan (1995) identified low profits among both manufacturers and retailers, and argued that the retailers' customers have gained power in terms of lower prices and better service. Both studies are carried out in a grocery retail setting, and it is uncertain whether the 
results can be transferred to other contexts. In timber trade, the brand values of the products are low, and therefore supplier power may be lower than in grocery retailing.

\section{Resource-based theory}

The logic of implementing supplier integration and the mediators of supplier integration success can be understood through an analysis of how the resources available in the dyad can be used to achieve a competitive advantage. Analysis of how resources create competitive advantages is the most integral part of resource-based theory (Barney, 1991).

The resource-based model takes internal resources as a starting point for developing a strategy. Superior financial performance is achieved by using the internal resources to create unique capabilities and a competitive advantage over competitors (Grant, 1991; Hunt and Morgan, 1995). Resources can be any assets, capabilities, organizational processes, attributes, information, or knowledge that enable a firm to improve its effectiveness and efficiency (Barney, 1991).

Typically, studies based on a resource-based view have focused solely on the internal characteristics of firms (Barney, 1991). Gulati et al. (2000) identified several consequences that appear when a network is introduced as an important consideration in strategy. One of these consequences is that the search for inimitable resources should "extend beyond the boundaries of the firm" (Gulati et al., 2000, p. 207) and that a network plays an important role in how value-creating resources are developed. When firms that hold complementary resources cooperate, they can achieve an inter-organizational competitive advantage (Dyer and Singh, 1998).

Das and Teng (2000) examined strategic alliances through a resource-based view, and suggested that the rationale for engaging in alliances is the value-creating potential that stems from pooled resources. These authors acknowledged that pooled resources could create value by being either complementary (when firms have dissimilar resources) or supplementary (when firms have similar resources). Harrison et al. (2001) drew on insights from acquisitions theory and stated that resources should be complementing each other in alliances. In other studies, the resource-based view has been used for quantitative examinations of how two firms engaged in an alliance can achieve a competitive advantage through having complementary resources (Hitt et al., 2000; Lin et al., 2009). In these investigations, firms engaged in partnering have been used as case studies. This was likely because partnering firms have a closer bond than, for example, firms in regular long-term relationships. However, the long-term relationships between supplier and retailer that supplier integration would require can also benefit from an analysis of how resources of the supplier and retailer complement each other. Strategically important activities such as the logistics operations (Bouzaabia et al., 2013) cross corporate boundaries. An analysis of resources available in the dyad can therefore determine which might be the most suitable actor for performing specific activities. 


\section{Resource dependence}

In resource-dependence theory, resources are described as the source of dependence. When one actor holds resources that are important to another, and when control over these resources is concentrated, dependence is created (Pfeffer and Salancik, 1978). Bacharach and Lawler (1986) similarly stated that dependence is accomplished by providing benefits to another actor. Having access to scarce resources that are important for another actor enables the focal company to provide benefits to that actor. Pfeffer and Salancik (1978) further described importance as being affected by the proportion of inputs or outputs that a resource represents for the other actor, and the other actor's ability to function without the resource. An integrated supplier is required to hold some resources that enable it to participate in the buyer's business. The importance and concentration of these resources then affects the buyer's dependence on the supplier. Often, knowledge is described as the primary source of dependence (Inkpen and Beamish, 1997). Dependence is then created when one actors possesses knowledge that another actor needs and when this knowledge is difficult to access from other sources.

In a relationship between a timber supplier and a BM, the two actors could both be dependent on each other (c.f. Pfeffer and Salancik, 1978). The BM could be dependent on the supplier's knowledge about the products and ability to manufacture the products, and the supplier could be dependent on the BM's position in the marketplace and its access to customers.

Power can be described as the inverse of dependence; one actor's power over another actor is equal to the latter actor's dependence on the former actor (Emerson, 1962). In the economics literature, the current share of profitability or value created is connected to exercised power, based on the logic that exercising power means that changes are made in the buyer-supplier relationship that increase the influencer's share of profit. This view has been adopted by several marketing scholars (e.g. Ailawadi et al., 1995; Messinger and Narasimhan, 1995; Cook and Henderson, 1998; Ailawadi, 2001). Using this reasoning, dependence or power can create changes in relative value capture between a supplier and retailer when power is exercised.

\section{Summary of literature review}

Based on the reasoning in the literature review, the enablers for implementing supplier integration are identified through resource dependence theory and the potential factors mediating the success of supplier integration are identified through resource-based theory.

The enablers for implementing supplier integration are what must be in place for supplier integration to occur. Without the enablers in place, the BM would not be willing to integrate the supplier in the assortment management. The enablers of supplier integration describe when the BMs are likely to adhere to the influence exerted on them through supplier integration. Here, the starting point of the analysis is resource dependence theory, as the BMs are likely reluctant to give up power to the suppliers if the benefits for them are not obvious.

The potential factors mediating the success of supplier integration are what determine the outcomes of supplier integration. Without the mediators in place, the outcomes, in terms of effectiveness and efficiency of the dyad, risk being negatively affected. To identify mediators for the success of supplier integration, resource-based theory is used. By understanding how 
the resources of the two actors in the dyad can complement each other, the competitiveness of the dyad and mediators for success of supplier integration can be determined.

\section{Research Approach}

\section{Research design}

A qualitative research approach was chosen for this study because inter-firm relationships are complex phenomena (Eisenhardt, 1989; Håkansson and Snehota, 1995; Yin, 2009) and because the role of suppliers is seldom taken into consideration in research on retailers' assortment management. By using an explorative study, new aspects that appeared during data collection could be identified and incorporated into the results. The case studied is the distribution channel through which a timber supplier provides builders' merchants with mouldings and planed timber products. The reasons for the choice of timber supplier and builders' merchants are discussed below.

\section{Case selection}

The timber supplier studied in this paper has an interest in engaging in BMs' assortment management and is therefore a good example of a supplier wanting to integrate in a retailer's business. The fact that the supplier operates in a stable market made it possible to study the company and its situation during a longer period of time without any major changes taking place. These arguments are related to the data accessibility and generalizability of the case (Saunders et al., 2007).

When finding BMs to incorporate into the study, purposive selection (c.f. Saunders et al., 2007) was used with the aim of capturing typical, yet heterogeneous, BMs. From the available BMs, three chains that differ greatly in terms of how they conduct their business were selected as the main focus in the case. In addition to the chains, a number of independent and smaller BMs were included in the study to provide a broader view of the market. The sampling of retailers was not carried out as a separate stage, but can instead be described as a continuous process (c.f. Dubois and Gadde, 2002).

\section{Data collection process}

Data collection was carried out during six visits to the UK, where the case company and its customers are located. The visits ranged in duration from two days to two weeks. The data was collected through participative observations and complemented with interviews. In addition to the participative observations and the interviews, secondary data in the form of sales and inventory data, industry press articles and annual reports were used to confirm the findings. By using multiple methods of data collection as a means of triangulation, the validity of the results was increased (Miles and Huberman, 1984; Yin, 2009).

The majority of the time in the UK was spent collecting data. During this time, I travelled around the country together with account managers from the timber supplier and visited BM branches. During the visits I observed the account managers, the employees in the BM branches, and the interactions between account managers and BM employees. 
In between the BM branch visits I spent numerous hours on the road together with the account managers. During this time I obtained a good insight into their daily routines, and I 'observed' their telephone conversations with customers and colleagues. This gave me an understanding of the context and the business I was studying. The telephone conversations gave an overview of how orders can be handled, and how problems that occur in daily operations can be dealt with.

During an early stage of the research process I spent two days in a BM branch, which gave me an understanding of the BM's daily business routines. I was able to engage in discussions with employees in different roles in the branch, and also observe their customers.

During all participations, a recurring theme of the discussions I initiated related to range and assortment. For example, I discussed opinions on, reasons for, and problems and challenges with the current assortment, as well as possible solutions to these problems and challenges. Altogether, I believe that my participative observations enabled me to understand the distribution channel and the actors in it to a sufficient extent.

In addition to the participative observations, a total of 72 interviews were conducted, as described in Table 1. Most of the interviews were informal and loosely tied to an interview guide. 27 of the interviews were unscheduled short interviews held with builders, joiners and other customers encountered in the BMs, and few of these lasted longer than 10 minutes. The remaining 45 interviews were longer, and were held with the timber supplier's and the BMs' employees.

Table 1: Interviews with different actors in the UK.

\begin{tabular}{|llll|}
\hline & $\begin{array}{l}\text { Short, } \\
\text { unscheduled }\end{array}$ & Scheduled & $\begin{array}{l}\text { Number of } \\
\text { respondents }\end{array}$ \\
\hline Timber supplier & 24 & 15 \\
\hline BMs & 21 & 15 \\
\hline $\begin{array}{l}\text { Builders, joiners, } 27 \\
\text { etc. }\end{array}$ & & 27 \\
\hline
\end{tabular}

The respondents in the interviews included a mix of persons in different positions, from high management to regular staff, and self-employed builders. Both large and small BMs were visited, as well as independent BMs and branches that are part of a chain. In this way, a broad view of the distribution channel was obtained. All interviews dealt with the product assortment of the BMs and the product range of the timber supplier. During the six visits, several questionnaires were developed. They were adapted to the type of respondent, as different respondents were likely to possess different kinds of information. The information sought for also developed during the research project. Some of the interviews had a cost perspective and others were more focused on customer demand. The interviews conducted in the initial stage of the data collection process were mainly focused on understanding how business is conducted today. The interviews in the latter stage of the data collection process focused mainly on why business was conducted in this way and how it could be developed. The resource-based view 
and resource dependence theory were used as a theoretical base when formulating the questionnaires. This meant that the questionnaires to a large extent focused on the resources of the actors and how they were used in their business.

\section{Data analysis}

In general, a high-level analysis of collected data is performed, where the gathered material is related to current theories. For the two aims of this paper, slightly different kinds of data analysis were conducted. For identifying the enablers of supplier integration, an analysis was made of what in the current state was missing or had to change for supplier integration to be implemented. For identifying the mediators for supplier integration, an analysis was made of what in the current state explained why supplier integration could succeed and what was missing for supplier integration to be successful. All collected data, in the form of recordings and field notes, was searched for information relevant to fulfil the aims of this study. This information was coded according to what area it concerned, what kind of characteristic it described, and what the consequence could be for the supplier's offering. The areas of concern were determined based on the literature review. They reflected both retailing issues such as pricing and assortment, as well as resource dependence and resource based theory issues such as internal resources, negotiations and value sharing. The coded data was then used as a basis for the analysis.

\section{The setting}

\section{The timber supplier}

The studied timber supplier is an importer, manufacturer and distributor of timber products in the UK. The supplier controls a large part of the supply chain, from the nurseries in which saplings, or young trees, are grown, to the forests, sawmills, and machining of the timber into finished products, all the way through to the distribution of products to BMs. This control over the supply chain is seen as a strong point for the company, and increases its reliability and trustworthiness as a knowledgeable timber supplier. This strength is also actively communicated to customers through the marketing message "we own the forest", and constitutes an important part of the offering.

Despite being used in its marketing, the company's knowledge about the supply chain is not used to suggest or influence which products BMs should purchase. The account managers have valuable insights into the BMs and their customers, but their role is to respond to customer demand, and therefore the collective knowledge held by them is not used to shape the offering of the timber supplier in a broader sense.

The account managers have a strong influence on what the product range of the timber supplier looks like and they introduce more products as customers demand them, without removing any. The company follows the ethos of never missing any opportunities to sell. Removing products is associated with a risk that customers will be disappointed and go somewhere else, and therefore it only happens when a product has not been sold for a long time, or has achieved insignificant sales during the recent years. The account managers are also rewarded through a commission scheme that encourages them to increase sales volumes, rather than profitability. 
To change what products BMs are buying, the relative pricing of individual products can be reviewed. Today, the timber supplier pricing is mainly based on what customers are willing to pay, and what is called the "role cost" of products, which is calculated from the cost of buying and manufacturing the product. However, at the time of the study, the role costs were outdated and did not take the product sales volume into account to a sufficient extent.

\section{The builders' merchants}

The builders' merchants in the UK are a heterogeneous group of companies, which vary greatly in how they run their businesses. Among the BMs in the UK there are a number of big companies with a nationwide presence. Other companies have several branches but only in one region. There is an on-going trend of consolidation within the industry, which is driven by the need to cut costs (Agapiou et al., 1998; Nord, 2005). However, there are still many independent branches left, which are often owned by the branch manager operating the business.

The smaller BM companies are sometimes part of a buying group, which increases their negotiating power in supplier relations. The companies that are part of a buying group are limited in their purchasing to the nominated suppliers, and the purchasing prices and delivery conditions are negotiated by the buying group. Independent BM branches that are not part of a buying group can choose what to order from the timber supplier's list of standard products. This product catalogue has several price lists with different levels attached to them to define the prices of the products. National BM chains negotiate their prices with less aid from the price lists, and place more effort into negotiating the prices of individual products. The primary financial measurement used in the national BM chains is return on capital employed (ROCE). In supplier negotiation, this means that not only is the purchasing price important, but also the payment days and how deliveries impact stock weeks.

Determining what and how many products to keep in a BM branch is an important task for BMs. One reason why BM chains often give branches control over what assortment to keep relates to their knowledge about regional demands, which is perceived to be very important by all actors studied in this case. In selecting an assortment, branches are highly influenced by nearby competitors and what has historically been used in that region. The main downside of letting BM branches select their own assortment is suggested to lie in their limited knowledge of the effect their assortments will have on the entire distribution channel, which means that they risk selling products that decrease distribution channel efficiency.

\section{Findings from the Case Study}

\section{Enablers of supplier integration}

In supplier integration, a supplier takes part in and influences a buyer's operations (Das et al., 2006; Yeung et al., 2009). Using supplier integration means that more effort is spent by the supplier on understanding the BMs' situation; this understanding acts as an add-on service in the offering to BMs (c.f. Oliva and Kallenberg, 2003). For supplier integration to happen, the influence from the supplier has to be allowed by the buyer. Enablers for supplier integration can therefore be found by identifying when the buyer is likely to allow influence from the supplier to be exerted. Exerting influence means that power is exercised and requires the buyer 
to be dependent on the supplier. Only when the supplier holds scarce resources important to the BM, will the BM be dependent on the supplier (Pfeffer and Salancik, 1978; Bacharach and Lawler, 1986). From the present study, two enablers were identified using this reasoning.

Selling to larger BM chains and BMs not specialized in timber: Integrating suppliers is not suitable for all BMs. For this reason, supplier integration might have varying appeal for different BMs. Empirical findings from the BM branches suggest that BMs specialized in timber products are likely to show less interest in the supplier's knowledge about the timber product assortment, as they consider themselves to be sufficiently knowledgeable already. In resource dependence terms, this means the utility of the supplier's knowledge is low for the $\mathrm{BM}$, reducing the BM's dependence on the supplier regarding assortment management. When participating in discussion between BMs and the supplier, it was also noted that it was difficult to convince independent BMs with only one or a few branches to implement supplier integration. The limited resources available for suppliers to promote changes in smaller BM chains makes the BMs unaware of how the knowledge of the supplier is useful for them, thus reducing the BMs dependence on the supplier. It was also noted that the independent merchants' managers have a more narrow view of the value generated by suppliers; they are mainly judging their suppliers based on price and quality of the products rather than how the supplier can help the BM achieve its goals. The central management of the larger BM chains did on the other hand mention that they wanted suppliers which could explain how their offering contributed to the goal achievement of the BM. Relating to the customer value hierarchy proposed by Woodruff (1997), supplier integration creates value in a way that is closely associated with a BM's goals and purposes, rather than desired product attributes. With the independent managers' view on value, the perceived utility of the suppliers' knowledge is limited. This finding is supported by Koufteros (2007) who found out that small firms do not achieve significant improvements in innovation as a result of supplier integration. Therefore, BMs with several branches and BMs that are not specialized in timber are more likely to be attracted by the expertise held by a timber supplier and more likely to integrate suppliers in their assortment management.

Trust: Trust is widely accepted to be a requirement for successful relationship marketing (Morgan and Hunt, 1994). This is equally true for supplier integration, and Yeung et al. (2009) claim that a buyer's trust positively influences supplier integration. The BMs have to trust an integrated supplier in letting the improvements of supplier integration benefit the BMs. A concern about how increased supplier influence would benefit the BM was stressed by the BMs in this study. Currently, many relationships between BMs and their suppliers are long-term, but based on contractual agreements rather than trust. A current offering from a supplier can be defined in terms of price, quality and delivery service, which is why there is little need for establishing a relationship built on trust. The details of an offering from an integrated supplier cannot easily be established in a contract; therefore, trust between supplier and BM is an important enabler of supplier integration. With an integrated supplier, the supplier's influence on the BM's assortment management also necessitates that the supplier is allowed access to certain data from the BM, further increasing the need for trust between the actors. This is 
supported by Elg (2008), who identifies trust between supplier and retailer as a key structural factor that makes firms more receptive towards information sharing.

\section{Mediators of supplier integration success}

Suppliers and BMs have different preconditions and are variously suited for obtaining the knowledge required for implementing supplier integration. In order for supplier integration to improve profitability in the dyad, several mediators must be in place. Using resource-based theory, if the dyad is to benefit from the supplier's integration in a BM's assortment, the supplier needs to have some useful knowledge of assortment management that the BM is lacking. In the present study, three mediators for supplier integration success have been identified.

Knowing demand in different retail formats: Retailers can hold hundreds of categories of products (Gooner et al., 2011), while suppliers often specialize in only one or a few product categories. Due to their specialization, the supplier's turnover in each product category is likely to be bigger than the BMs' turnover in that same category, given that the supplier is a fairly large company that supplies its products to several BM chains. The supplier's role may be better suited to understanding the total demand for its products, as it is usually supplying several BMs. BMs are in direct contact with the customers and are expected to have better knowledge about the demands for products. Today, many BMs have access to point-of-sales data and can make a detailed analysis of demand patterns. However, the supplier in the studied case is able to contribute to the assortment management of the BMs, using aggregated sales data from several BM chains to obtain an understanding of the demand for their products. The supplier then has a resource complementary to the resources of the BM (c.f. Dyer and Singh, 1998; Das and Teng, 2000). Education and experience of managers has been hypothesised to correlate with efficiency of retailers (Uyar et al., 2013). If suppliers should contribute with complementary resources, they therefore require knowledge of the differences in demand across retail formats. As chains tend to differ in the assortments they offer, the supplier in this study claims it can analyse how different combinations of products will affect sales. If this information is provided to the BMs supplied, the BMs are able to obtain knowledge that is lacking in other competing supplier-BM dyads, and use this resource to create a competitive advantage (c.f. Barney, 1991). In this way, BMs that integrate suppliers will be able to create an assortment that more effectively meets customer needs.

Understanding costs appearing in the dyad: Suppliers can play an important role in identifying and realising cost reductions related to the BMs' assortment management. The supplier in the studied case is responsible for most of the costs appearing in the distribution channel. The supplier also believes it is better suited to obtain an understanding of how the assortments provided by BMs are driving these costs. As the costs mainly appear within the domains of the suppliers, they could also be better at taking these costs into consideration in the management of their own product range. The potential knowledge about costs held by the supplier is a resource that is both important for the BM and not available from any other actor. Therefore, in accordance with resource complementarity thinking (c.f. Dyer and Singh, 1998; Das and Teng, 2000), suppliers that understand how assortment drives costs in the dyad are better suited for influencing the management of the assortment. The supplier's understanding of costs appearing in the dyad could therefore be a mediator for supplier integration success. 
Local circumstances not affecting demand: Many of the BM branches included in the study claim that they have an understanding of how local circumstances affect demand in the individual branches. Many characteristics of an individual branch, such as its location, size and customer base, are usually well known by the branch manager. Because of this, the branch manager is often better suited to determine how the assortment should be adapted to local characteristics. In many BMs, the local knowledge is described as an important resource for assortment management. There are however other BMs where local circumstances is only perceived to have a limited effect on demand and assortment management. Local characteristics that do not affect demand to a great extent therefore mediate the success of supplier integration, as the resources held by the supplier complements the resources of the BM to a further extent. On the other hand, if local characteristics greatly affect demand, the expected benefit of supplier support in assortment management is reduced.

\section{Summary of findings}

A summary of the enablers of supplier integration and the mediators for supplier integration success are seen in Table 2. The enablers and mediators are categorized according to whether they are established in the relationships between the studied timber supplier and the BMs. One of the mediators for supplier integration success is in place in the studied context, and the others are perceived to be partially in place. This means that implementation of supplier integration might have a positive effect on the effectiveness and efficiency of the dyad. However, the enablers of supplier integration are not entirely in place, which can likely explain why the supplier in the studied context is not yet integrated into the assortment management of the BM.

Table 2: Summary of the enablers of supplier integration and mediators for supplier integration success.

\begin{tabular}{|c|c|c|}
\hline & $\begin{array}{l}\text { Enablers } \\
\text { - Resource Dependence }\end{array}$ & $\begin{array}{l}\text { Mediators } \\
\text { - Resource-based View }\end{array}$ \\
\hline In place & & $\begin{array}{l}\text { - Knowing demand in } \\
\text { different retail formats }\end{array}$ \\
\hline Partially in place & $\begin{array}{l}\text { - Selling to larger BM chains } \\
\text { and BMs not specialized in } \\
\text { timber }\end{array}$ & $\begin{array}{l}\text { Understanding costs } \\
\text { appearing in dyad } \\
\text { - } \quad \text { Local circumstances } \\
\text { not affecting demand }\end{array}$ \\
\hline Not in place & $\begin{array}{l}\text { The BM trusts the supplier } \\
\text { to use its resources to } \\
\text { benefit both parties }\end{array}$ & \\
\hline
\end{tabular}

\section{Conclusion}

The findings from the case study can be used for drawing generalized conclusions about supplier integration and how it affects a dyad consisting of a supplier and a retailer. 


\section{Enablers of supplier integration}

The case study has revealed two enablers that could increase the likelihood for supplier integration to be used. The enablers are characteristics describing the supplier, the retailer and their relationship. In order for supplier integration to be used, the retailer must believe that it will benefit from the new way of managing the assortment. The enablers are therefore derived from resource dependence logic and relate to the retailer's perception of the benefit of an integrated supplier's offering.

Proposition 1: The likelihood that a supplier and a retailer will implement supplier integration is positively affected by (a) the retailer's format as a large chain with several product categories represented in its stores and (b) the retailer's trust in the supplier to use its resources to benefit both parties.

\section{Mediators of supplier integration success}

A number of mediators have been identified that will impact the effectiveness and efficiency of supplier integration. Based on the reasoning that supplier integration is effective and efficient when the supplier holds resources that are important to the assortment management of the retailer, a number of mediators can be identified that describe situations when suppliers are likely to hold those important resources. It is vital to describe the resources of the supplier in relation to the resources of the retailer. The mediators of supplier integration success therefore describe situations in which the retailers are likely to lack resources important in assortment management. In these situations, there is an opportunity for a supplier to contribute to the assortment management of the retailer and thereby improve effectiveness and efficiency in the dyad.

Proposition 2: Effectiveness and efficiency of supplier integration is mediated by (a) the number of different retail formats represented by the retailers, $(b)$ the ability of the supplier to determine cost drivers in its operations and (c) a homogeneous market, meaning that local circumstances have limited effect on demand.

Previous literature has highlighted the need for resource complementarity in alliances (Harrison et al., 2001) and claimed that a motif for engaging in an alliance can be access to resources (Das and Teng, 2000). The results of the present study lead to the conclusion that the retailer's lack of a resource makes it important that the supplier holds that resource, i.e. the utility of a supplier's resource increases when its customer lacks it. This extends previous research on resource complementarity, by showing an example of a retailer and a supplier that benefit from resource complementarity even though they are not engaged in a strategic alliance.

\section{Discussion}

\section{Theoretical contributions}

This paper contributes to literature on supplier integration, as it explores when supplier integration is likely to happen, and when it is likely to succeed. Previous studies have provided 
inconclusive results regarding the effects of supplier integration (Fabbe-Costes and Jahre, 2008). This paper follows the advice of Van der Vaart and van Donk (2008) to study individual buyer-supplier relationships in order to better understand supplier integration. It is concluded that contextual factors affect when supplier integration is going to happen and when it is going to succeed. The likelihood that a retailer is willing to integrate a supplier in its business is determined by characteristics of the retailer business and the retailer's trust in the supplier. The likelihood that supplier integration will succeed is then mediated by other characteristics of the retailer, the resources held by the supplier, and characteristics of the market where the retailer operates.

The paper also contributes to retail management, as it provides examples of when a supplier's resources can be used by retailers. Collaboration between suppliers and retailers is encouraged by for example Varley (2006) and Aastrup et al. (2007), as the actors then can benefit from their complementary resources to a further extent. This study explores when collaboration might be successful, and when it is less likely to succeed. In research on category captainship arrangements, the focus is often on anti-trust challenges and the lack of intra-brand competition (e.g. Desrochers et al., 2003; Bandyopadhyay et al., 2009; Gooner et al., 2011). This study complements these studies and explores other challenges in supplier integration that might also be associated with category captainship.

\section{Managerial implications}

The case studied in this paper involves supplier integration in the assortment management of a BM. In this setting, an integrated supplier's offering will vary depending on the context and look different in different situations. Based on the findings in this paper, contextual factors can be identified that affects when to use supplier integration and what an integrated supplier's offering might look like.

The degree of integration depends on the BM's openness towards supplier integration. From the enablers of supplier integration, inspiration can be found regarding which situations are suitable for high or low degrees of integration. The enablers are not absolute measures, but rather conditions that can be more or less fulfilled. The higher the extent to which the enablers are fulfilled, the more integration is suitable. Because of this, high degrees of integration is suitable when BMs are larger chains not specialized in timber, and when the BMs' trust in the supplier is high.

When a low degree of integration is suitable, the supplier could for example present a list of standard and special products, where the BM is encouraged to select products from the standard list. In addition to the separation of products, the supplier could give the standard products more competitive prices. It is also possible to separate between more than two lists of products and have different price levels, and delivery conditions for the different lists. In this way, the supplier only implicitly encourages the BM to select certain products. The degree of supplier integration in the assortment management of the BM is therefore low.

When a high degree of integration is suitable, the supplier could present suggestions on what products to replace with other products For example, replacement suggestions can be made if the supplier has a product available that is similar to a product in a BM's current assortment, 
and when the supplier's products are known to be selling well in other branches. The suggested replacements could also be given more competitive prices. Possibly, the supplier could provide specific examples of what a complete assortment can include. The supplier then provides more specific suggestions for the BM. The degree of supplier integration in the assortment management is therefore high.

As seen from the discussion above, integration can take place both through communication of the product range and through prices and delivery conditions for the products. By assigning lower prices or offering discounts for some products, the BMs are encouraged to choose these products over other alternatives. In a similar fashion, keeping high stock levels and offering fast deliveries of some products will also influence BMs in their assortment management. From a managerial point of view, these are possible ways in which supplier integration can be realised. The different supplier integration tactics suggested are also adapted to suit different situations.

\section{Further research}

The case study in this paper cannot give definite answers to what the most important enablers of supplier integration or mediators of supplier integration success are. Still, based on the enablers and mediators that were considered important in this particular setting, a number of general enablers and mediators are suggested. To determine the accuracy of these propositions, further empirical research is required. For example, it would be rewarding to study buyersupplier relationships in other settings and industries.

The mediators of supplier integration success in this paper are identified from the complementary resources held by the actors. According to resource-based literature, competitive advantages can be achieved in many other ways. Das and Teng (2000) describe how resources in an alliance can be useful if they are either complementary or supplementary. It would therefore be interesting to further explore how supplementary resources can mediate supplier integration success. Dyer and Singh (1998) describe resource complementarity as merely one of four ways to achieve inter-organizational competitive advantage. The three remaining sources of competitive advantage - relation-specific assets, knowledge-sharing routines and effective governance - would also be interesting to explore further in order to better understand the outcome of supplier integration.

\section{References}

Aastrup, J., Grant, D. B. and Bjerre, M., (2007), "Value Creation and Category Management through Retailer-Supplier Relationships", The International Review of Retail, Distribution and Consumer Research, Vol. 17 No. 5, pp. 523-541.

Agapiou, A., Flanagan, R., Norman, G. and Notman, D., (1998), "The Changing Role of Builders Merchants in the Construction Supply Chain", Construction Management and Economics, Vol. 16 No. 3, pp. 351-361.

Ailawadi, K. L., (2001), "The Retail Power-Performance Conundrum: What Have We Learned?", Journal of Retailing, Vol. 77 No. 3, pp. 299-318. 
Ailawadi, K. L., Borin, N. and Farris, P. W., (1995), "Market Power and Performance: A CrossIndustry Analysis of Manufacturers and Retailers", Journal of Retailing, Vol. 71 No. 3, pp. 211248.

Anderson, J. C., Håkansson, H. and Johanson, J., (1994), "Dyadic Business Relationships within a Business Network Context", The Journal of Marketing, Vol. 58 No. 4, pp. 1-15.

Bacharach, S. B. and Lawler, E. J., (1986), "Power Dependence and Power Paradoxes in Bargaining", Negotiation Journal, Vol. 2 No. 2, pp. 167-174.

Bandyopadhyay, S., Rominger, A. and Basaviah, S., (2009), "Developing a Framework to Improve Retail Category Management through Category Captain Arrangements", Journal of Retailing and Consumer Services, Vol. 16 No. 4, pp. 315-319.

Barney, J., (1991), "Firm Resources and Sustained Competitive Advantage", Journal of management, Vol. 17 No. 1, pp. 99.

Bouzaabia, R., Bouzaabia, O. and Capatina, A., (2013), "Retail Logistics Service Quality: A Cross-Cultural Survey on Customer Perceptions", International Journal of Retail and Distribution Management Vol. 41 No. 8, pp. 627-647.

Brege, S., Nord, T. and Nordigården, D., (2012), "Design of Value Chains in Volume-Intensive Market Segments - Exploiting Economies of Scale, Scope and Integration", paper presented at Biennial Meeting of the Scandinavian Society of Forest Economics, Hyytiälä, Finland.

Burt, S. L. and Sparks, L., (2003), "Power and Competition in the Uk Retail Grocery Market", British Journal of Management, Vol. 14 No. 3, pp. 237-254.

Cao, M. and Zhang, Q., (2011), "Supply Chain Collaboration: Impact on Collaborative Advantage and Firm Performance", Journal of Operations Management, Vol. 29 No. 3, pp. 163-180.

Collins, A., (2002), "The Determinants of Retailers' Margin Related Bargaining Power: Evidence from the Irish Food Manufacturing Industry", International Review of Retail, Distribution \& Consumer Research, Vol. 12 No. 2, pp. 165-189.

Cook, K. and Henderson, J., (1998), "Power and Firm Profitability in Supply Chains: French Manufacturing Industry in 1993", Strategic Management Journal, Vol. 19 No. 10, pp. 909-926.

Cox, A., (2007), "Transactions, Power and Contested Exchange: Towards a Theory of Exchange in Business Relationships", International Journal of Procurement Management, Vol. 1 No. 1, pp. 38-59.

Das, A., Narasimhan, R. and Talluri, S., (2006), "Supplier Integration-Finding an Optimal Configuration", Journal of Operations Management, Vol. 24 No. 5, pp. 563-582.

Das, T. K. and Teng, B.-S., (2000), "A Resource-Based Theory of Strategic Alliances", Journal of management, Vol. 26 No. 1, pp. 31-62. 
Desrochers, D. M., Gundlach, G. T. and Foer, A. A., (2003), "Analysis of Antitrust Challenges to Category Captain Arrangements", Journal of Public Policy \& Marketing, Vol. 22 No. 2, pp. 201-215.

Dubois, A. and Gadde, L.-E., (2002), "Systematic Combining: An Abductive Approach to Case Research", Journal of Business Research, Vol. 55 No. 7, pp. 553-560.

Dyer, J. H. and Singh, H., (1998), "The Relational View: Cooperative Strategy and Sources of Interorganizational Competitive Advantage", Academy of Management Review, Vol. 23 No. 4, pp. 660-679.

Eisenhardt, K. M., (1989), "Building Theories from Case Study Research", The Academy of Management Review, Vol. 14 No. 4, pp. 532-550.

Elg, U., (2008), "Inter-Firm Market Orientation and the Influence of Network and Relational Factors", Scandinavian Journal of Management, Vol. 24 No. 1, pp. 55-68.

Emerson, R. M., (1962), "Power-Dependence Relations", American Sociological Review, Vol. 27 No. 1, pp. 31-41.

Fabbe-Costes, N. and Jahre, M., (2008), "Supply Chain Integration and Performance: A Review of the Evidence", International Journal of Logistics Management, The, Vol. 19 No. 2, pp. 130154.

Fadairo, M., (2013), "Why Include Royalties in Distribution Contracts? Evidence from France", International Journal of Retail and Distribution Management, Vol. 41 No. 8, pp. 566-583.

Farris, P. W. and Ailawadi, K. L., (1992), "Retail Power: Monster or Mouse?", Journal of Retailing, Vol. 68 No. 4, pp. 351.

Fearne, A., Duffy, R. and Hornibrook, S., (2005), "Justice in Uk Supermarket Buyer-Supplier Relationships: An Empirical Analysis", International Journal of Retail \& Distribution Management, Vol. 33 No. 8, pp. 570-582.

Frohlich, M. T. and Westbrook, R., (2001), "Arcs of Integration: An International Study of Supply Chain Strategies", Journal of Operations Management, Vol. 19 No. 2, pp. 185-200.

Gadde, L.-E., (2004), "Activity Coordination and Resource Combining in Distribution Networks - Implications for Relationship Involvement and the Relationship Atmosphere", Journal of Marketing Management, Vol. 20 No. 1-2, pp. 157-184.

Galbraith, C. S. and Stiles, C. H., (1983), "Firm Profitability and Relative Firm Power", Strategic Management Journal, Vol. 4 No. 3, pp. 237-249.

Gooner, R. A., Morgan, N. A. and Perreault, W. D., (2011), "Is Retail Category Management Worth the Effort (and Does a Category Captain Help or Hinder)?", Journal of Marketing, Vol. 75 No. 5, pp. 18-33. 
Grant, R. M., (1991), "The Resource-Based Theory of Competitive Advantage: Implications for Strategy Formulation", California Management Review, Vol. 33 No. 3, pp. 114-135.

Guan, W., (2010), "Developments in Distribution Chanels - a Case Study of a Timber Production Distribution Channel", Licentiate thesis, Institute of Technology, Linköping University.

Gulati, R., Nohria, N. and Zaheer, A., (2000), "Strategic Networks", Strategic Management Journal, Vol. 21 No. 3, pp. 203-215.

Harrison, J. S., Hitt, M. A., Hoskisson, R. E. and Ireland, R. D., (2001), "Resource Complementarity in Business Combinations: Extending the Logic to Organizational Alliances", Journal of management, Vol. 27 No. 6, pp. 679.

Hingley, M. K., (2005a), "Power Imbalance in Uk Agri-Food Supply Channels: Learning to Live with the Supermarkets?", Journal of Marketing Management, Vol. 21 No. 1-2, pp. 63-88.

Hingley, M. K., (2005b), "Power to All Our Friends? Living with Imbalance in SupplierRetailer Relationships", Industrial Marketing Management, Vol. 34 No. 8, pp. 848-858.

Hitt, M. A., Dacin, M. T., Levitas, E., Arregle, J. L. and Borza, A., (2000), "Partner Selection in Emerging and Developed Market Contexts: Resource-Based and Organizational Learning Perspectives", Academy of Management Journal, Vol. 43 No. 3, pp. 449-467.

Hunt, S. D. and Morgan, R. M., (1995), "The Comparative Advantage Theory of Competition", Journal of Marketing, Vol. 59 No. 2, pp. 1-15.

Håkansson, H. and Snehota, I., (1995), "Developing Business Relationships in Business Networks", International Thomson Business Press, London.

Inkpen, A. C. and Beamish, P. W., (1997), "Knowledge, Bargaining Power, and the Instability of International Joint Ventures", Academy of Management Review, Vol. 22 No. 1, pp. 177-202.

Kim, D.-Y., (2013), "Relationship between Supply Chain Integration and Performance", Operations Management Research, Vol. 6 No. 1-2, pp. 74-90.

Koufteros, X. A., Edwin Cheng, T. and Lai, K.-H., (2007), "“Black-Box" and "Gray-Box" Supplier Integration in Product Development: Antecedents, Consequences and the Moderating Role of Firm Size", Journal of Operations Management, Vol. 25 No. 4, pp. 847-870.

Lawson, B., Cousins, P. D., Handfield, R. B. and Petersen, K. J., (2009), "Strategic Purchasing, Supply Management Practices and Buyer Performance Improvement: An Empirical Study of Uk Manufacturing Organisations", International Journal of Production Research, Vol. 47 No. 10, pp. 2649-2667.

Lin, Z., Yang, H. and Arya, B., (2009), "Alliance Partners and Firm Performance: Resource Complementarity and Status Association", Strategic Management Journal, Vol. 30 No. 9, pp. 921-940. 
Lindblom, A., Olkkonen, R., Ollila, P. and Hyvönen, S., (2009), "Suppliers' Roles in Category Management: A Study of Supplier-Retailer Relationships in Finland and Sweden", Industrial Marketing Management, Vol. 38 No. 8, pp. 1006-1013.

Mentzer, J. T., Min, S. and Zacharia, Z. G., (2000), "The Nature of Interfirm Partnering in Supply Chain Management", Journal of Retailing, Vol. 76 No. 4, pp. 549-568.

Messinger, P. R. and Narasimhan, C., (1995), "Has Power Shifted in the Grocery Channel?", Marketing Science, Vol. 14 No. 2, pp. 189.

Miles, M. B. and Huberman, A. M., (1984), "Qualitative Data Analysis: A Sourcebook of New Methods", Sage Publications, Beverly Hills.

Mohr, J. and Spekman, R., (1994), "Characteristics of Partnership Success: Partnership Attributes, Communication Behavior, and Conflict Resolution Techniques", Strategic Management Journal, Vol. 15 No. 2, pp. 135-152.

Morgan, R. M. and Hunt, S. D., (1994), "The Commitment-Trust Theory of Relationship Marketing", Journal of Marketing, Vol. 58 No. 3, pp. 20-38.

Narasimhan, R. and Kim, S. W., (2002), "Effect of Supply Chain Integration on the Relationship between Diversification and Performance: Evidence from Japanese and Korean Firms", Journal of Operations Management, Vol. 20 No. 3, pp. 303-323.

Nord, T., (2005), "Structure and Developments in the Solid Wood Value Chain: Dominant Saw Milling Strategies and Industrialized Housing", Samhällsbyggnad/träbyggnad, Luleå Tekniska Universitet.

Oliva, R. and Kallenberg, R., (2003), "Managing the Transition from Products to Services", International Journal of Service Industry Management, Vol. 14 No. 2, pp. 160-172.

Pfeffer, J. and Salancik, G., (1978), "The External Control of Organizations: A Resource Dependence Perspective", Harper and Row, New York, NY.

Saunders, M., Lewis, P. and Thornhill, A., (2007), "Research Methods for Business Students", 4th Edition, Prentice Hall, Harlow.

Uyar, A., Bayyurt, N., Dilber, M. and Karaca, V., (2013), "Evaluating Operational Efficiency of a Bookshop Chain in Turkey and Identifying Efficiency Drivers", International Journal of Retail \& Distribution Management, Vol. 41 No. 6, pp. 331-347.

Vaart, T. v. d. and Donk, D. P. v., (2008), "A Critical Review of Survey-Based Research in Supply Chain Integration", International Journal of Production Economics, Vol. 111 No. pp. $42-55$.

Vachon, S. and Klassen, R. D., (2008), "Environmental Management and Manufacturing Performance: The Role of Collaboration in the Supply Chain", International Journal of Production Economics, Vol. 111 No. 2, pp. 299-315. 
Varley, R., (2006), "Retail Product Management", Second edition, Routledge, New York.

Weber, J. A., (2001), "Partnering with Resellers in Business Markets", Industrial Marketing Management, Vol. 30 No. 2, pp. 87-99.

Villena, V. H., Gomez-Mejia, L. R. and Revilla, E., (2009), "The Decision of the Supply Chain Executive to Support or Impede Supply Chain Integration: A Multidisciplinary Behavioral Agency Perspective*", Decision Sciences, Vol. 40 No. 4, pp. 635-665.

Woodruff, R., (1997), "Customer Value: The Next Source for Competitive Advantage", Journal of the Academy of Marketing Science, Vol. 25 No. 2, pp. 139-153.

Yeung, J. H. Y., Selen, W., Zhang, M. and Huo, B., (2009), "The Effects of Trust and Coercive Power on Supplier Integration", International Journal of Production Economics, Vol. 120 No. pp. 66-78.

Yin, R. K., (2009), "Case Study Research: Design and Methods", Fourth Edition, Sage Publication, London.

Zhao, X., Huo, B., Flynn, B. B. and Yeung, J. H. Y., (2008), "The Impact of Power and Relationship Commitment on the Integration between Manufacturers and Customers in a Supply Chain", Journal of Operations Management, Vol. 26 No. 3, pp. 368-388. 